\title{
Understanding the Mechanism of Antioxidant Potential of Organochalcogens in Rat's Brain Preparation
}

Waseem Hassan $^{1,2 *}$, Senthil Narayanaperumal ${ }^{1}$, Matheus M. Santos ${ }^{1}$, Kashif Gul ${ }^{1,2}$, Imdad Ullah Mohammadzai ${ }^{2}$, Antonio L. Braga $^{1}$, Oscar Dorneles Rodrigues ${ }^{1}$ and Joao B. T. Rocha ${ }^{1}$

${ }^{1}$ Departamento de Química, Centro de Ciências Naturais e Exatas, Universidade Federal de Santa Maria, Santa Maria, CEP 97105-900, RS, Brazil ${ }^{2}$ Institute of chemical sciences, University of Peshawar, Peshawar -25120, Khyber Pukhtunkhwa, Pakistan

\begin{abstract}
In the quest to explore mechanism of action of organochalcogens a series of them are tested for their structuralactivity relationship using rat's brain preparation. Dichalcogenides are better anti-oxidants than structurally analogues mono- chalcogenides. Effects of electron donating and withdrawing groups have been explored and explained in detail. We have also proved that structural isomerisation does not influence the anti-oxidant activity of these compounds.
\end{abstract}

Keywords: Organochalcogens; Structure-Activity Relationship and Oxidative Stress

\section{Introduction}

Oxidative stress is an important biochemical condition causing several human diseases. This stress is linked to the presence of unusually high concentrations of toxic reactive species, which include reactive oxygen species (ROS) reactive nitrogen species and unbound, adventitious metal ions [1]. Most of these species are highly oxidizing, readily modifying redox sensitive proteins and enzymes, as well as attacking membranes and DNA. The living cell contains a number of important antioxidants and antioxidant catalysts. Their presence counteracts oxidative stress and also neutralizes a range of oxidizing species. Ascorbate, NADH, melatonin, trolox and GSH are common antioxidants that frequently occur in the cell. However, disruption in homeostasis can result in oxidative stress and tissue injury. Thus to respond to ROS more effectively, compounds can be envisaged that combine a range of antioxidant activities in one chemically simple molecule $[2,3]$.

Organoselenium chemistry is a very broad and exciting field with many opportunities for research and development of applications. Organoselenium compounds have become attractive synthetic targets because of their chemio-region and stereoselective reactions [4] and their useful biological activity [5]. In fact, a variety of organoselenium compounds with potential antioxidant activity, including ebselen analogues, benzoselenazolinones, diaryl diselenides, selenamide and related derivatives have been reported in a variety of pathological situations [6-10]. The mechanism(s) underlying the toxic effect of organochalcogens are not completely understood but certainly involves the reaction of chalcogenides with endogenous thiols [11] however there is still scarcity of data about the mechanism of action of these organoselenium compounds acting as anti-oxidant agents.

Nitric oxide (NO) released from sodium nitropruside (SNP) is endogenously produced reactive specie. It is also recognized as a neurotransmitter in the central nervous system (CNS) [12,13]. It can mediate biological actions ranging from vasodilatation, neurotransmission, inhibition of platelet adherence and aggregation, and killing of pathogens mediated by macrophages and neutrophiles. High concentrations of $\mathrm{NO}$ are toxic and interact with superoxide $\left(\mathrm{O}_{2}^{-}\right)$ to form peroxynitrite $\left(\mathrm{ONOO}^{-}\right)$[12]. Peroxynitrite is a strong oxidant and, at physiological $\mathrm{pH}$, is protonated to form peroxynitrous acid
(HOONO), a relatively long-lived oxidant agent, which spontaneously decomposes to form another potent oxidant with the reactivity of a hydroxyl-like radical [14] which could initiate lipid peroxidation (LPO) $[12,15]$.

Keeping in view the above stated issue we took a step in this regard and are reporting the importance of a chemically multidimensional approach towards antioxidant characterization. In this communication we will describe how chemical changes to a series of organoselenium compounds alter their biochemical rather antioxidant activities. We have tested the efficacy of these compounds against sodium nitropruside (SNP) induced thio-barbituric acid reactive species (TBARS) formation in rat's brain preparation.

\section{Material and Methods}

\section{Synthesis of diorganyl selenides}

The unsymmetrical diorganyl selenides and sulphides were synthesised using the literature procedure [16,17]. Commercially available diphenyl diselenide (CAS No: 1666-13-3), and diphenyl ditelluride (CAS No: 32294-60-3) were purchased and used for the experiments. Analysis of the ${ }^{1} \mathrm{HNMR}$ and ${ }^{13} \mathrm{CNMR}$ spectra showed that both compounds obtained presented analytical and spectroscopic data in full agreement with their assigned structures. The chemical purity of the compounds (99.9\%) were determined by GC/HPLC.

\section{Animals}

Adult male wistar rats from our own breeding colony (250-350 g) were maintained in an air-conditioned room $\left(22-25^{\circ} \mathrm{C}\right)$ under natural lighting conditions, with water and food (Guabi, RS, Brazil) ad libitum.

*Corresponding author: Waseem Hassan (PhD), Departamento de Química Centro de Ciências Naturais e Exatas, Universidade Federal de Santa Maria Santa Maria, CEP 97105-900, RS, Brazil, E-mail: waseem_anw@yahoo.com

Received October 31, 2011; Accepted November 16, 2011; Published November 18, 2011

Citation: Hassan W, Narayanaperumal S, Santos MM, Gul K, Mohammadza IU, et al. (2011) Understanding the Mechanism of Antioxidant Potential of Organochalcogens in Rat's Brain Preparation. Pharm Anal Acta S3:002. doi:10.4172/2153-2435.S3-002

Copyright: @ 2011 Hassan W, et al. This is an open-access article distributed unde the terms of the Creative Commons Attribution License, which permits unrestricted use, distribution, and reproduction in any medium, provided the original author and source are credited. 
Citation: Hassan W, Narayanaperumal S, Santos MM, Gul K, Mohammadzai IU, et al. (2011) Understanding the Mechanism of Antioxidant Potential of Organochalcogens in Rat's Brain Preparation. Pharm Anal Acta S3:002. doi:10.4172/2153-2435.S3-002

Animals were used according to the guidelines of the Committee on Care and Use of Experimental Animal Resources, School of Veterinary Medicine and Animal Science of the University of São Paulo, Brazil.

\section{Tissue preparation}

Animals were anesthetized with ether and killed by decapitation. Brain was quickly removed, placed on ice, and homogenized within $10 \mathrm{~min}$, in $10 \mathrm{mmol} / \mathrm{l} \mathrm{Tris} / \mathrm{HCl}$ buffer, $\mathrm{pH} 7.4$ (in 10 volume). The homogenate was centrifuged at $4000 \times g$ at $4{ }^{\circ} \mathrm{C}$ for $10 \mathrm{~min}$ to yield a low speed supernatant fraction (S1) that was used immediately for
TBARS assay (Puntel et al. 2007 ).

\section{Lipid peroxidation assay}

Tissue homogenate was prepared by homogenization as described above. An aliquot of $100 \mu \mathrm{l}$ of $\mathrm{S} 1$ was incubated for $1 \mathrm{~h}$ at $37^{\circ} \mathrm{C}$ in the presence of organochalcogens (final concentrations range of $(0-100$ $\mu \mathrm{M})$, with and without the prooxidant i.e. sodium nitropruside (SNP) at final concentration of $10 \mu \mathrm{M}$. Production of TBARS were determined as described by method of Ohkawa et al. [18] except that the buffer of color reaction have a $\mathrm{pH}$ of 3.4. The color reaction was developed

\begin{tabular}{|c|c|c|c|c|c|c|c|c|c|c|}
\hline \multirow{2}{*}{ \# } & \multirow{2}{*}{$\mathbf{R}$} & \multirow{2}{*}{ R' } & \multirow{2}{*}{ X } & \multirow{2}{*}{ Product } & \multicolumn{6}{|c|}{ nmol of MDA (TBARS) } \\
\hline & & & & & Control (0) & 1 & 5 & 10 & 50 & 100 \\
\hline C-1 & $\mathrm{Ph}$ & $\mathrm{Ph}$ & $\mathrm{Br}$ & & $542 \pm 21$ & $538 \pm 22$ & $540 \pm 23$ & $563 \pm 22$ & $523 \pm 12$ & $511 \pm 21^{\mathrm{a}}$ \\
\hline C-2 & $\mathrm{Ph}$ & $\mathrm{PhCH}_{2}$ & $\mathrm{Cl}$ & & $542 \pm 19$ & $549 \pm 19$ & $550 \pm 21$ & $564 \pm 31$ & $526 \pm 19$ & $509 \pm 12^{a}$ \\
\hline C-3 & o- $\mathrm{MeOC}_{6} \mathrm{H}_{4}$ & $\mathrm{PhCH}_{2}$ & $\mathrm{Cl}$ & & $542 \pm 19$ & $541 \pm 21$ & $559 \pm 12$ & $547 \pm 18$ & $535 \pm 21$ & $443 \pm 23^{b}$ \\
\hline C-4 & p- $\mathrm{MeOC}_{6} \mathrm{H}_{4}$ & $\mathrm{PhCH}_{2}$ & $\mathrm{Cl}$ & & $542 \pm 34$ & $511 \pm 15$ & $523 \pm 28$ & $565 \pm 18$ & $484 \pm 22$ & $307 \pm 32^{\circ}$ \\
\hline C-5 & o- $-\mathrm{MeC}_{6} \mathrm{H}_{4}$ & $\mathrm{PhCH}_{2}$ & $\mathrm{Cl}$ & & $542 \pm 12$ & $547 \pm 23$ & $548 \pm 32$ & $534 \pm 32$ & $548 \pm 32$ & $469 \pm 13^{b}$ \\
\hline C-6 & $\mathrm{p}-\mathrm{MeC}_{6} \mathrm{H}_{4}$ & $\mathrm{PhCH}_{2}$ & $\mathrm{Cl}$ & & $542 \pm 21$ & $561 \pm 12$ & $545 \pm 31$ & $555 \pm 21$ & $507 \pm 12$ & $348 \pm 23^{\circ}$ \\
\hline C-7 & $\mathrm{Ph}$ & o- $-\mathrm{MeC}_{6} \mathrm{H}_{4} \mathrm{CH}_{2}$ & $\mathrm{Br}$ & & $542 \pm 23$ & $541 \pm 31$ & $551 \pm 12$ & $533 \pm 12$ & $496 \pm 12$ & $440 \pm 21^{b}$ \\
\hline C-8 & $\mathrm{Ph}$ & m-MeC ${ }_{6} \mathrm{H}_{4} \mathrm{CH}_{2}$ & $\mathrm{Br}$ & & $542 \pm 32$ & $551 \pm 23$ & $568 \pm 17$ & $546 \pm 23$ & $498 \pm 18$ & $459 \pm 14^{b}$ \\
\hline C-9 & $\mathrm{Ph}$ & p- $-\mathrm{MeC}_{6} \mathrm{H}_{4} \mathrm{CH}_{2}$ & $\mathrm{Br}$ & & $542 \pm 12$ & $527 \pm 24$ & $536 \pm 16$ & $541 \pm 31$ & $482 \pm 21$ & $448 \pm 31^{b}$ \\
\hline$C-10$ & $\mathrm{p}-\mathrm{ClC}_{6} \mathrm{H}_{4}$ & $\mathrm{PhCH}_{2}$ & $\mathrm{Cl}$ & & $542 \pm 32$ & $736 \pm 21$ & $701 \pm 32$ & $730 \pm 18$ & $746 \pm 23$ & $780 \pm 22^{\mathrm{e}}$ \\
\hline
\end{tabular}

Table 2: Effect of Diphenyl Diselenide (DPDS) and Diphenyl Ditelluride (DPDT) on TBARS production in rat's brain preparation. TBARS are expressed as nmol of MDA $/ g$ of tissue. Data are presented as mean \pm S.E.M. $(n=5)$. Asterisk presents the significant effect of SNP while different letters represent significant effect of the tested compounds. 
by adding $200 \mu \mathrm{l} 8.1 \%$ SDS to S1, followed by sequential addition of $500 \mu \mathrm{l}$ acetic acid/ $\mathrm{HCl}(\mathrm{pH} 3.4)$ and $500 \mu \mathrm{l} 0.8 \%$ of thiobarbituric acid (TBA). This mixture was incubated at $95^{\circ} \mathrm{C}$ for $1 \mathrm{~h}$. TBARS produced were measured at $532 \mathrm{~nm}$ and the absorbance was compared to that of a standard curve obtained using malondialdehyde (MDA).

\section{Results and Discussion}

Table 1-2 shows the anti-oxidant behavior of all tested compound in brain homogenate. It is considered that the electron donating groups increase the electronic density on selenium atom and theoretically it can increase the anti-oxidant activity. To prove the hypothesis we introduced an electron donating (mesomerically i.e. methoxy group) on C-2. We further managed to synthesize two isomers. First we introduced a methoxy group at ortho position (C-3). The introduction of the electron donating group at ortho position significantly improved the anti-oxidant behavior. In the same way when a methoxy group was introduced at para position (C-4) the resulting compound showed significantly higher antioxidant potential than C-3. This result proves that para isomer is a better anti-oxidant than ortho isomer. To verify the position effect, another electron donating group, this time inductively electron donating group i.e. methyl $\left(\mathrm{CH}_{3}\right)$ group was introduced. And as expected the ortho substituted $\left(\mathrm{CH}_{3}\right)$ group $(\mathrm{C}-5)$ showed significantly higher anti-oxidant behavior than C-1 \& C-2. Similarly (C-6) with para $\left(\mathrm{CH}_{3}\right)$ group displayed higher antioxidant activity than $(\mathrm{C}-5)$. The results demonstrate that the antioxidant activity significantly depend on the electronic effects of the substituents on the aromatic ring.

To prove the hypothesis that electron donating group present on the phenyl ring which has a direct bond with selenium would be a

\begin{tabular}{|c|c|}
\hline Concentration $(\mu \mathrm{M})$ & nmol of MDA (TBARS) \\
\hline \multicolumn{2}{|c|}{ Diphenyl Diselnide (DPDS) } \\
\hline Basal (B) & $218 \pm 16$ \\
\hline SNP-Induced a* & $351 \pm 31^{*}$ \\
\hline $\mathrm{SNP}+4 \mu \mathrm{M}^{\mathrm{a}}$ & $334 \pm 30$ \\
\hline $\mathrm{SNP}+10 \mu \mathrm{M}^{\mathrm{b}}$ & $196 \pm 12$ \\
\hline $\mathrm{SNP}+40 \mu \mathrm{M}^{\mathrm{b}}$ & $154 \pm 19$ \\
\hline$S N P+100 \mu M^{b}$ & $67 \pm 21$ \\
\hline \multicolumn{2}{|c|}{ Diphenyl Ditelluride (DPDT) } \\
\hline Basal (B) & $274 \pm 21$ \\
\hline SNP-Induced a* & $536 \pm 34^{*}$ \\
\hline $\mathrm{SNP}+1 \mu \mathrm{M}^{\mathrm{a}}$ & $503 \pm 25$ \\
\hline $\mathrm{SNP}+1.2 \mu \mathrm{M}^{\mathrm{b}}$ & $341 \pm 19$ \\
\hline $\mathrm{SNP}+1.4 \mu \mathrm{M}^{\mathrm{c}}$ & $213 \pm 17$ \\
\hline $\mathrm{SNP}+1.6 \mu \mathrm{M}^{\mathrm{e}}$ & $44 \pm 7$ \\
\hline
\end{tabular}

Table2: Effect of Diphenyl Diselenide (DPDS) and Diphenyl Ditelluride (DPDT) on TBARS production in rat's brain preparation. TBARS are expressed as nmol of $\mathrm{MDA} / \mathrm{g}$ of tissue. Data are presented as mean \pm S.E.M. $(n=5)$. Asterisk presents the significant effect of SNP while different letters represent significant effect of the tested compounds. better anti-oxidant. We synthesized three- isomers i.e. C-7, C-8 and $\mathrm{C}-9$ where the same electron donating group i.e. $\left(\mathrm{CH}_{3}\right)$ was introduced on benzyl ring (This ring does not have a direct bond with selenium). All resulting compound showed significantly lower antioxidant activity than C-6 where methyl $\left(\mathrm{CH}_{3}\right)$ group was directly attached to phenyl ring (bonded directly with selenium). These structural isomeric effects confirm the supposition that isomerisation have a profound effect on the anti-oxidant activity of organoselenium compounds. We took another step in this regard and introduced an electron withdrawing group directly attached to phenyl ring i.e. C-10. The results indicated that $\mathrm{C}-10$ does not posses any anti-oxidant activity rather at highest concentration it showed pro-oxidant behavior.

Earlier studies have indicated that photodegradation of SNP ultimately produces NOd, $[(\mathrm{CN}) 5-\mathrm{Fe}]^{3+}$ and $[(\mathrm{CN}) 4-\mathrm{Fe}]^{2+}$ species $[19,20]$. NO is a molecule that is regarded as a universal neuronal messenger in the central nervous system, in the pathophysiology of such disorders as Alzheimer's and Parkinson's diseases, stroke, trauma, seizure disorders, etc. [21,22]. The result presented in (Table 1-2) indicated that organoselenium exerted an antioxidant effect on in vitro SNP induction of lipid peroxidation in brain homogenate. The NO released from SNP added in the incubation medium can undergo reaction with superoxide radicals to afford peroxynitrite. Peroxynitrite is a potent free radical and is capable of inducing oxidative damage to several biomolecules, including membrane phospholipids [19]. Thus, organoselenium might be conferring its protective effect by decomposing lipid hydroperoxides resulted from lipid peroxidation chain reaction caused by NO released from SNP. Another possible explanation might be the direct interaction between organoselenium and SNP or its derivatives. It should be noted that the organoselenium anti-oxidant activity was not modified by change in pro-oxidant as apparent from results.

It would be important to mention that when the diselenide bond of diphenyl diselenide is disrupted, two selenols can be yielded, differently from monoselenides, improving the catalytic reaction that is of particular significance to living cells. This reflects in the better antioxidant potential of diphenyl diselenide (a diselenide) (Table 2) than all mono selenides (Table 1). The anti-oxidant potency of DPDT (Table 2) can be explained by the fact that organotellurium compounds are readily oxidized from the divalent to the tetravalent state. This property makes them attractive as scavengers of reactive oxidizing agents such as hydrogen peroxide, hypochlorite, and peroxyl radicals, and as inhibitors of lipid peroxidation in chemical and biological systems [23]. This study also suggests that diorganoyl ditelluride are more reactive than structurally related diorganoyl mono/diselenide compounds. The higher potency of DPDT can be explained, essentially due to the higher electro negativity in relation to carbon associated with a larger atomic volume of the tellurium atom.

\section{Acknowledgments}

The author is grateful for the financial support of TWAS_CNPq. Waseem Hassan is a beneficiary of the TWAS CNPq doctoral fellowship program. J.B.T. Rocha gratefully acknowledges the financial support of CAPES SAUX, CNPq VITAE and FAPERGS.

\section{References}

1. Valko M, Rhodes CJ, Moncol J, Izakovic M, Mazur M (2006) Free radicals, metals and antioxidants in oxidative stress-induced cancer. Chemico-Biological Interactions 160: 1-40

2. Angel I, Bar A, Horovitz T, Taler G, Krakovsky M, et al. (2002) Metal ion chelation in neurodegenerative disorders. Drug Development and Research 56: 300-309. 
Citation: Hassan W, Narayanaperumal S, Santos MM, Gul K, Mohammadzai IU, et al. (2011) Understanding the Mechanism of Antioxidant Potential of Organochalcogens in Rat's Brain Preparation. Pharm Anal Acta S3:002. doi:10.4172/2153-2435.S3-002

3. Perry G, Cash AD, Srinivas R, Smith MA (2002) Metals and oxidative homeostasis in Alzheimer's disease. Drug Development and Research 56: 293-299.

4. Moro AV, Nogueira CW, Barbosa NBV, Menezes PH, Rocha JBT et al. (2005) Highly stereoselective one-pot producers to prepare bis- and tris chalcogenide alkenes via addition of disulfides and diselenides to terminal alkynes $\mathrm{J}$ Org Chem 70: 5257-5268.

5. Nogueira CW, Zeni G, Rocha JBT (2004) Organoselenium and organotellurium compounds: toxicology and pharmacology. Chem Rev 104: 6255-6285.

6. Sies, $H$ (1993) Ebslen, a selenooraganic compounds as glutathione peroxidase mimic, Free Radic Biol Med 14: 313-323

7. Yamagushi T, Sano K, Takakura K, Saito I, Shinohara Y et al. (1998) Ebslen in acute ischemic stroke: a placebo controlled, double-blind clinical trial. Stroke 29. $12-17$

8. Saito I, Asano T, Sano K, Takakura K, Abe H et al. (1998) Neuroprotective effect of an antioxidant, Ebselen, in patients with delayed neurobiological deficits after aneurismal subarachnoid hemorrhage. Neurosurgery 42: 269-277.

9. Hassan W, Ibrahim M, Rocha JB (2009) Towards the mechanism and comparative effect of diphenyl diselenide, diphenyl ditelluride and ebselen under various pathophysiological conditions in rat's kidney preparation Chemico-Biological Interactions 182: 52-58

10. Hassan W, Ibrahim M, Deobald AM, Braga AL, Nogueira CW et al. (2009) pHDependent Fe (II) pathophysiology and protective effect of an organoselenium compound FEBS Letters 583: 1011-1016

11. Maciel EN, Bolzan RC, Braga AL, Rocha JB (2000) Diphenyl diselenide and diphenyl ditelluride differentially affect $\delta$-aminolevulinate dehydratase from liver, kidney, and brain of mice. J Biochem Mol Toxicol 14: 310-319

12. Snyder SH, Bredt DS (1991) Nitric oxide as a neuronal messenger. Trends Pharmacol Sci 12: 125-128.
13. Moncada S, Palmer RM, Higgs EA (1991) Nitric oxide: physiology, pathophysiology, and pharmacology. Pharmacol Rev 43: 109-142.

14. Beckman JS, Beckman TW, Chen J, Marshall PA, Freeman BA (1990) Apparen hydroxyl radical production by peroxynitrite: implications for endothelial injury from nitric oxide and superoxide, Proc Natl Acad Sci U.S.A 87: 1620-1624.

15. Yang G, Candy TE, Boaro M, Wilkin HE, Jones P et al. (1992) Free radical yields from the homolysis of peroxynitrous acid, Free Radic Biol Med 12 327-330.

16. Narayanaperumal $S$, Alberto $E F$, Andrade FM, Lenardão EJ, Taube PS et al. (2009) Ionic liquid: an efficient and recyclable medium for synthesis of unsymmetrical diorganyl selenides promoted by Inl, Org Biomol Chem 7 : $4647-4650$

17. Brindaban C Ranu, Samanta S (2003) Remarkably Selective Reduction of the $\alpha, \beta$-Carbon-Carbon Double Bond in Highly Activated $\alpha, \beta, \gamma, \delta$-Unsaturated Alkenes by the $\mathrm{InCl}_{3}-\mathrm{NaBH}_{4}$ Reagent System. J Org Chem 68: 7130-7132

18. Ohkawa H, Ohishi N, Yagi K (1979) Assay for lipid peroxides in animal tissues by thiobarbituric acid reaction, Anal Biochem 95: 351-358.

19. Bates JN, Baker MT, Guerra R, Harrison DG (1991) Nitric oxide generation from nitroprusside by vascular tissue. Biochem Pharmacology 42: 157-165.

20. Arnold WP, Longneeker DE, Epstein RM (1984) Photodegradation of sodium nitroprusside: biologic activity and cyanide release. Anesthesiology 61: 254 60.

21. Bolanos JP, Almeida A (1999) Roles of nitric oxide in brain hypoxia - ischemia Biochim Biophys Acta 1411: 415-436.

22. Castillo J, Rama R, Davalos A (2000) Nitric oxide-related brain damage in acute ischemic stroke. Stroke 31: 852-857.

23. Jacob C, Arteel GE, Kanda T, Engman L, Sies H (2000) Water soluble organotellurium compounds: catalytic protection against peroxynitrite and release of zinc from metallothionein, Chem Res Toxicol 13: 3-9.
This article was originally published in a special issue, Antioxidants handled by Editor(s). Dr. Anand lyer, Hampton University School of Pharmacy, USA 